\title{
The fall and rise of class analysis in British sociology, $1950-2016$
}

Mike Savage

The past fifteen years has seen a dramatic revival of interest in social class in the UK. Class - often in intersection with other inequalities such as gender, race and ethnicity - is indeed, the main topic within contemporary British sociology. This is a remarkable recovery. Having been criticised as a tired and redundant concept in the 1990s, criticised by many of the key sociologists in the UK, such as Zygmunt Bauman (1982), Ulrich Beck (1992, Beck and Beck-Gernsheim, 2002), and Anthony Giddens (1991), the concept has returned with a vengeance. How? Why?

This paper reviews and explains this remarkable revival and unravels the prospects for class analysis into the future. I am concerned to bring out the extent to which this recovery is due to specific factors of the British, or indeed English case, in the spirit of Edward Thompson's (1967) famous insistence of the "peculiarities of the English". This will assist researchers in other parts of the world in assessing which parts of the British revival may be of relevance to them, and which may only be meaningful in the English context. I explore three distinctive generations of class analysis in British social science. In each of these the concept of class has different kinds of stakes, mobilises distinctive intellectual and political communities, and interfaces in differing ways with scholarly debates.

My key argument is that the concept of social class is distinctive because of its unusual role in straddling popular and academic discourse. There are numerous scholarly concepts which have powerful purchase in academic debates but are not extensively deployed in public or political debate: consider for instance "discourse", 
"structure", "assemblage", "interaction" and so forth. The concept of class, however, has failed to be domesticated as a purely scholarly concept, and slips into wider public debate. But furthermore, the concept of class used in the public and political realm does not simply circulate as a topic of popular discussion, but also looks to engage with academic reflections. There are numerous examples of the "bleeding" of academic concepts into everyday parlance such as gentrification, ethnicity, gender, globalisation but in these cases the direction of travel tends to be clear, with the public taking up - and sometimes contesting - terms initially defined in the academic arena. However, in the case of social class, the direction of travel is more genuinely bi-directional, with academic authority being actively contested by those outside these circuits. The power of the class concept rests in its ambivalent location betwixt and between academic, political and public fields, and this is something to be celebrated as a means of recognising the fundamental political stakes tied up with the concept of class.

In developing this argument, I will show how the "golden age" of British class analysis from 1950 to the mid-1970s was characterised by the heady fusion of British social science around a particular focus on the working class as harbinger of progressive social change. The decline of class analysis from the mid-1970s to the late 1990 s was due not only to the way that social change radically eroded what had been understood as "traditional" working class culture, but was also due to the way that powerful academic siloes defined the concept in largely technical terms which thereby insulated their wider appeal and interest and in the process undermined the popular interest in class itself. The revival of the concept since 2000 reflects the broadening of academic interests in class - inspired especially by Bourdieu's capacity to open up the cultural aspects of class in telling ways - and the capacity of academic debates to engage with the public. Whereas the decline of class analysis was associated with the concept being used in highly specialised ways, it now operates as a term of dialogue and argument across boundaries.

This paper pulls on themes I have developed in other publications, notably on the rise of the "social science assemblage" (Savage, 2010), and reflects also on my own thinking on social class (Savage, 1987; Savage, 2000; Savage, et al., 2005; Bennett et al., 2009; Savage et al., 2013; 2015). My own intellectual trajectory is indeed telling. My doctoral studies, when I was a student between 1980 and 1984 at the northern English university of Lancaster (Savage, 1987) was one of the last studies to have been carried out under the spirit of the initial heroic generation of class analysis. It was a detailed historical study of the mobilisation of manual workers in the northern industrial town of Preston between 1880 and 1940 (a short distance from Lancaster). It looked back, though also tried to update, Marx- 
ist influenced arguments about class politics. In the mid-1980s, I moved to the English south, as a post-doctoral Fellow at the University of Sussex. The world here looked very different from the bleak decaying industrial urban fabric of the north: new service and hi-tech industries seemed to offer a glimpse of a different kind of future. Reflecting on these experiences led me to become interested in the formation of the middle classes (Savage et al., 1992; Butler and Savage, 1995), and it was this focus on the higher levels of the class structure which was to characterise the regeneration of class analysis in the $21^{\text {st }}$ century, and which have especially come to the fore in my recent work with the Great British Class Survey (Savage et al., 2015). Amidst these changes, my key reference points remained stable, with Marx and Bourdieu being the key influences, inflected by feminist debates. As I will show below, the work of the great British sociologist, John Goldthorpe, has also been hugely significant.

My paper thus serves as an original contribution to my long term interesting in how best to use the concept of class productively, as a means of developing agendas and proving an effective platform for social science to inform public debate.

The heroic generation: the rise of class analysis in British social science 1950-1975

It is hardly an exaggeration to say that the emergence of British social science in the years after 1945 depended on the dramatic mobilisation of the question of class in British society. Different kinds of "class analysis" were crucial devices by which the emerging social sciences justified their expertise and authority. And, furthermore, these studies proved to be foundational in the sense that they defined the canon against which later works defined themselves - sometimes critically - against.

Sociology is the quintessential and highly telling case. In 1945 sociology barely existed as a specialist discipline in the UK, though a conception of sociology as an overarching concern bringing together history and the social sciences into a broad interpretation of social change was very strong (see Goldman, 2004; Platt, 2004). Just 25 years later, sociology had become one of the major social sciences, being taught in most universities and with an especially strong presence in the new, modern, "plateglass" 1960s universities such as Essex, Lancaster, Warwick and York, where it was championed as part of the intellectual modernisation of British society.

How had it done this? The key benchmark works which had established the distinctive intellectual profile of British sociology had a focus entirely devoted to class, and more particularly to the "working class". This ranged from T. H. Marshall's Citizenship and social class, (1951) through the ethnography of a mining village in the brilliant Coal is our life (Dennis et al., 1954), to Willmott and Young's Family 
and kinship in East London (1958), David Lockwood's The black coated worker (1958), to John Goldthorpe and David Lockwood's The affluent worker (1968/69), Paul Willis's Learning to labour (1975), and John Goldthorpe's Class structure and social mobility in modern Britain (1980). Many of the generation of sociologists who were also to become prominent from the 1970s also wrote extensively about social class - with Anthony Giddens being an especially prominent example.

Let me pull out the paradigmatic significance of this remarkable generation of British sociologists Firstly, we see a focus on the nature and stakes of the working class as a central concern. For Marshall, it was only by extending citizenship to include social welfare that the working classes could be admitted into full membership of society. For Willmott and Young, understanding the working class family was central to underscoring the power of community relations in modern Britain. For Goldthorpe and Lockwood, the extent to which the working class still existed as a distinctive class, set apart from "bourgeois" or middle class values, was fundamental to their interests in how far "the affluent worker" was still recognisably "working class". These concerns fed also into Goldthorpe's class structural approach to social mobility which he introduced through his fundamental interventions in social mobility research during the 1970s and were brought together in his 1980 Class structure and social mobility in modern Britain ${ }^{1}$. This heroic generation was fixated on the prospects for the working class to bring about social change, and more particularly by the ambivalent positon of the working class within British society, at the one moment being a central figure in bringing about the first industrial society in the world, but at another moment remaining outside the "gentlemanly", cosy world of the British establishment.

The significance of the working class for this heroic generation of sociologists was not incidental. It was fundamental to demonstrating the importance of sociology as a means of unravelling the significance of a key "outsider" social group which lay outside of, or in a fraught relationship with, the established upper and middle classes, and which thereby lay outside the purview of more established disciplines - such as economics or anthropology. And we can also note that it was from the basis of this compelling work that other disciplines took their lead. Thus, the Marxist historian E. P. Thompson's The making of the English working class was written in dialogue with sociological conceptions of class and stratification. But we can also identify the development of psephology in Britain, and the study of party political alignments,

1. The only apparent exception to this focus on the working class might be seen to be Lockwood's Black coated worker, which was ostensibly a study of clerical workers. Here, by underscoring their key status and work differences which clerks had over manual workers, this study implicitly had major implications for underscoring the importance of the working class. 
as strongly informed by this conception of the centrality of the working class as outsiders (see e.g. Pulzer, 1967).

This leads onto a second point. This sociology was implicitly or explicitly highly political, and all of the key figures made no bones about the political significance of their work. The power of Marxism was central here, with the sociologists attempting to challenge revolutionary formulations through elaborating more complex or subtle versions of their analysis of class than might be expected from a literal rendition of Marxist theory. This is nowhere more apparent than for Michael Young, who had written the Labour Party manifesto in 1945 and was a major figure in social democratic thinking. But it was also true in somewhat different ways for T. H. Marshall, who clearly articulated the Fabian LSE tradition to elaborate a conception of citizenship which sought to include the working classes. In short, there were direct political stakes in debates about class, with academic and political arguments cross fertilising each other.

Thirdly, these interventions also elaborated a raft of methodological repertoires which became canonical for sociology itself, as well as the social sciences more broadly. These methods were championed explicitly as devices which allowed those who had previously been outside the purview of social research to gain some kind of voice. The qualitative in-depth interview and the representative survey were central here. Both of these proved means of eliciting accounts and views of a wider range of people outside the educated middle classes, and hence providing a more balanced understanding of social divisions as a whole. As I emphasise in my study of social change in Britain after the second world war (Savage, 2010), the sample survey allowed new aggregate groups - such as social classes - to be identified and categorised in ways which "lifted social groups out of the landscape" and created a vocabulary of social groups which came to have huge significance.

This heroic generation was therefore truly formative, not only in establishing a powerful form of scholarship, but also in forging a set of research tools which came to have much wider provenance within the social sciences as a whole. These tools allowed a new kind of social group - the working class - whose voices and identities had been obscured by the dominant genteel inflection of British culture, to be heard. These methods were part of a radical current during the 1960s which swept into British public life and which "made the working class visible". The first major British soap opera, Coronation street, set in northern working class Salford; the gritty realist novels of Shelagh Delaney; Alan Sillitoe, Stan Barstow, and Barry Hines; the BBC's famous Play for today dramas, extending into the celebrated drama of Dennis Potter; the visibility of distinctly working class actors, notably Michael Caine; and perhaps above all the take-off of popular music, led by the Beatles, all 
defined this period as that in which the voices of the working class - as articulated by a new generation of cultural intermediaries - were mobilised as never before and found a certain place in British society.

Before we move on, let me reflect on some features of this generation, for my argument is that this was a very peculiar moment, which was shortly to be undercut by emerging social trends. The working class was very largely seen as "white": the 1960 s was the last decade when it was the white working class, rather than ethnic minorities, who were the prime "outsiders knocking to come in" ${ }^{2}$. It was also focused on men. Although the situation was already changing dramatically as a result of feminist politics and changing labour market and personal relationships, the 1960s was the last decade when women could largely be left out of the picture - or, as with Willmott and Young - be predominantly identified as mothers. Thirdly, the world of the working class was being deconstructed at the very moment that it finally was to have its place in British culture - with the radical programme of public housing renewal and the final phases of slum clearance, as well as the continue decline of manufacturing industry.

In short, this heroic generation of sociology was also an elegiac and romantic one: it finally brought the white male working class fully into visibility at the very same time that the social foundations of this formation were beginning to be radically undermined. It was ultimately unsustainable. And this is nowhere better demonstrated in the last great work from this tradition, Paul Willis's Learning to labour (1975). Here the world of working class boys is rendered as hopeless: rejecting the academic culture, these boys embrace a world of manual labour which is being dismantled in front of them - so preparing them for the bleak years of de-industrialised Britain from the mid-1970s.

The decline of class analysis 1970-2000

I have argued that the great tradition of class analysis established in Britain in the immediate post war decades was unsustainable. It was premised on a model of the white male worker which could only be seen as nostalgic in the context of late $20^{\text {th }}$ century Britain. It is therefore completely explicable why growing interests in gender inequality and changing position of women, and concerns with racism and the position of ethnic minorities could only appear to undermine the project of class analysis as a whole.

2. Though we should also be aware of considerable scholarly and popular interest in immigration which was already apparent in the 1950 s and 1960 s. 
This was a particular issue because the sociological models used to study class focused strongly on questions of social cohesion and what was identified by Giddens (1973) as "class structuration" or Goldthorpe (1980) as "class formation": how individuals in the same class position might bond together to become aware of their position and unite to champion a form of progressive politics. The solidaristic and cohesive worlds of the working class, defined by common relationships to production and the workplace, were the template here for understanding why and how class mattered. This approach had an appeal when there was evidence of solidaristic class politics, whether through trade unions, community mobilisation, or whatever, but this was unable to deal with the fragmentation of social relations embedded in the "neo-liberal" shift towards a marketised economy from the 1970s. And so it was inevitable that the dramatic de-industrialisation of Britain from the 1970s alongside the deregulation of economic regulation and marketization of public services, could only be interpreted as undermining class - as it had been historically understood in the heroic age.

In this context, the work of John Goldthorpe and his associates proved a crucial intellectual move in saving a specific understanding of social class, in a form which insulated it from these challenges. In his earlier writings in the 1960s and 1970s, Goldthorpe was very much part of the heroic generation. Especially in the Affluent Worker project, he was pre-occupied with understanding the working class, and his argument that they had not become "middle class" was a bedrock of sociological analysis thereafter. From the later 1970s, he subtly shifted his focus. In developing the Nuffield class schema for which he was to become famous, he detached it from a wider conceptual baggage of theories of exploitation or domination. Instead class was defined in much more "scientistic" terms derived from the nature of employment relationships. Here he differentiated between those occupations associated with a diffuse "service relationship" and those associated with a "labour contract" 3

This was a fundamentally powerful move, since Goldthorpe was therefore able to define class in operational ways which did not depend on any baggage about class formation or solidaristic identities, nor on politicised theories of class, and in ways which provided a relational analysis of class which differentiated working, intermediate and service classes. Indeed, he increasingly insisted on the individualistic assumptions which his class schema embedded, as a means of distancing his approach from versions of the "heroic" generation (see e.g. Goldthorpe, 1979; Goldthorpe in Clark et al., 1990; Goldthorpe and Marshall, 1992).

3. This approach to class is amply discussed by Goldthorpe (2000), Savage et al. (1992), Butler and Savage (1995) and Savage (2000). See Gordon Marshall et al. (1988) for a good overview. 
This account of class was in no way called into question by de-industrialisation, or the decline of overt class politics, or changing forms of class cultures. Indeed, these became questions which could be analysed using this class schema. Thus, famously, Anthony Heath deployed the Nuffield class schema to help explain the electoral weakness of the Labour Party during the 1980s. It was in this vein that Goldthorpe and Marshall recounted the "promising future of class analysis" in a famous article written in 1992 which challenged the "declinist" view that class no longer mattered.

By also clearly providing a class schema which could be effectively operationalised using measures of occupation and employment status, Goldthorpe's approach also permitted the generation of comparable class schema across different nations, and hence the prospect of the class schema allowing effective comparison across nations in a way which had previously been extremely difficult because of the previous nationally specific modes of aggregating occupations to national schemas, ranging from the Blau-Duncan index in the us to the distinctive French approach (Boltanski, 1979).

There is no doubt that Goldthorpe's move was very important in rescuing a specific form of class analysis in a period when the grounding on which older versions of class analysis was being cut away. It also proved highly prescient in lending itself to the increasing quantification of social mobility research and analyses of stratification, notably in his championing of log-linear modelling as permitting analysis of relative rates of social mobility. However, this perspective also came at a certain cost, which have become more apparent as the years moved on.

Firstly and most importantly, Goldthorpe's approach shunted the question of class into a technical issue of measurement. This had the effect of sundering the wider public interest and engagement with issues of class. And, by defining class as a specific kind of 'variable', its overarching significance became less clear. The problems this has led to have become increasingly evident in the past twenty years. Golddthorpe's class schema has not proved effective at highlighting increasing income differences. Even though economists showed increasingly marked disparities between the top and bottom deciles of the earnings distribution but this did not straightforwardly map onto differences between classes as measured by the EGP class. Of course, since the EGP class schema does not seek to be defined in terms of income, this does not undermine it, but it makes its relevance for unpicking spiralling levels of inequality much less clear.

Secondly, in seeking to render class as a discrete variable, and through his own personal responses to criticisms of his earlier work, Goldthorpe had the effect of distinguishing class from processes such as gender, ethnicity and age. Once again, the advantages of this move are clear, in seeking to place the concept of class on a clearer basis, but in holding class apart from wider intersectionalities of inequality, 
the overall remit of the concept could potentially be reduced. In the British case this was compounded by the way that Goldthorpe had proved resistant to feminist analysis, in particular.

My point, therefore, is that the huge merits of Goldthorpe's approach came at the cost of reducing class to a specifically variable which lost its capacity to engage with the public and political questions of the day, as well as the arguments of other social scientists.

The revival of class analysis

Class analysis in Britain in 2000 was therefore in a strange position: on the one hand, great advances in measurement issues and in the championing of a high profile class schema which proved a powerful measure of class in numerous arenas of inquiry. On the other hand, this had come at the expense of limiting the range and scope of the concept of class, and ruling out many of the key social changes of the time as necessarily centrally involved in class. By reducing class to a measurement issue, the wider appeal had been lost. The revival of class analysis in the past twenty years has depended on re-opening the wider agenda of class analysis and demonstrating the losses of defining class as a discrete variable.

There are three fundamental underpinnings of this intellectual move. Firstly has been the dramatic growth of inequality in Britain since the 1980s. In the mid-1970s, during the years of the Callaghan Labour Government, income inequality reached its low point. Tax rates were progressive, with high marginal taxes being imposed on large earners and property owners. From the early 1980s, and the relaxation of tax rates on high earners, and on non-domiciled wealth - this picture shifted rapidly, driven furthermore by London's role as centre for global finance. Over a very short time, Britain shifted from being one of the more equal, to being one of the most unequal nations in the developed world. Burgeoning economic inequalities were thus rapidly taken up in the media and in public debate in a way which regenerated huge public interest once more in understanding how class was changing (see Atkinson, 2015; Savage et al., 2015; Piketty, 2014; Wilkinson and Pickett, 2010).

Secondly, was ample and accumulating evidence that class still mattered to people, even though it was not necessarily a badge of collective pride, as it had been delineated in the heroic generation. Beverley Skeggs' Formations of class and gender published in 1997 proved a foundational text here. She showed how young, marginalised working class women in the older industrial areas of the English midlands had lives stamped by the experience of class inequality, but that this led them to "disidentify from class". My own qualitative research with 200 north British "middle class" residents in the 
late 1990s made a related argument (see Savage et al., 2003; 2005). Most of these respondents did not straightforwardly see themselves as belonging to a class in the "heroic" way, and often told a complicated story of straddling classes or being socially mobile. However, class clearly meant a great deal to them in terms of understanding social inequality. I called this "the paradox of class" - that as social inequalities increased, so people's subjective class membership declined. However, the lack of direct class consciousness did not mean that class was not emotionally significant for instance in terms of experiences of snobbery or elitism. To put this another way, class may not have been so significant in terms of its collective identities, but it was strongly experienced as part of an individual's sense of self (see Savage, 2000, for a full statement of this line of argument).

Thirdly was the growing interest in more granular approaches to inequality, which went beyond a broad focus on large scale class aggregates such as articulated in Goldthorpe's class schema. The work of Grusky and Weedon $(2005 ; 2008)$ or of economists focusing on small scale income groups pointed at the value of more focused and specific analysis, especially at the top levels of the class structure. The potential of new forms of big data is also important here (see Savage and Burrows, 2007).

Fourthly, a key intellectual force was Pierre Bourdieu's sociology which came to be increasingly influential in British sociology, and it came to offer a number of crucial theoretical resources for a new kind of class analysis. Bourdieu, famously, did not use the concept of class extensively, and instead was more focused on his interests in capital, but in the British context his thinking proved highly germane for fostering new currents in the discipline. He offered a number of intellectual resources to the growing revival of British class analysis. Most importantly, his "republican” approach to social analysis did not fixate on the working class as the key progressive social force in the way which had been typical of the heroic generation in Britain. Indeed, his presumption was rather that the working classes were disorganised and isolated as a result of their lack of capitals, and his emphasis that popular culture was characterised by the "culture of necessity" insisted on the limited horizons of the worst off. By contrast, his focus was on how the dominant classes came to be dominant, unravelling the economic, social and cultural capital which permitted them to acquire, reproduce, and convert their privileges. This approach was much more productive in shedding light on Britain in the early $21^{\text {st }}$ century because it could be used to focus on the upper and middle classes who had been the beneficiaries of economic and social change. It transformed what David Lockwood identified as the "problematic of the proletariat" towards a perspective able to critically dissect the more privileged classes.

He was also able to provide an alternative to the heroic generations emphasis on class consciousness and identity, through his concept of "mis-recognition", or what 
Skeggs was to term "dis-identification". For Bourdieu, power operates through the "naturalisation" of social relations. Socially and politically constructed gender divisions can thus be interpreted as the result of "natural" differences between men and women so making them appear outside issues of public concern. This argument thus provided a mechanism for explaining why people might not be class conscious, even in the midst of a highly class divided society. For instance, insofar as inequalities are "naturalised" as the product of differing amounts of motivation, skill, or natural ability, they might not be registered as class inequality. This focus on misrecognition thus resolved the "paradox of class".

Furthermore, Bourdieu's focus was to take attention away from class as a discrete variable, towards class as the contingent outcome of the operation of capitals, habitus and fields. Rather than fixing class as one discrete entity, it was thus seen as a more fluid outcome of other mechanisms, in a way which permitted more flexibility in how the concept could be used, and furthermore could engage with public debates. $\mathrm{He}$ offered a conceptual vocabulary with the question of culture and class. This concern had been central to the heroic generation, as the pivotal writings of EP Thompson, Richard Hoggart and Raymond Williams made clear, but the implication of Goldthorpe's move was to bracketed out issues of culture from class, by making it into a purely employment based variable which did not require that class consciousness be manifest in order to demonstrate the salience of class. But nothwithstanding the deftness of this move, it is the cultural aspects of class that are often salient to people, and which also are seen to be the very "stuff" of class.

The "cultural turn" in class analysis has been hugely significant (see Devine, 2004; Devine et al., 2005; Crompton, 2008), and was also highly pertinent to the take up of Bourdieu's thinking by researchers interested in the changing character of consumption, notably Alan Warde in his pioneering studies of food (1997), as well as by Featherstone (1987), and Lash and Urry (1987; 1995). It was through this means that Bourdieu was seen to offer a distinctive approach to the analysis of material culture and consumption practices which had considerable interest in demonstrating the ongoing importance of class divisions in these areas.

The initial use of Bourdieu's sociology was primarily in qualitative studies, often focusing on analyses of education or consumption, and hence did not directly compete with the Goldthorpe paradigm (e.g. Skeggs, 1997). However, this began to change as a result of the Cultural Capital and Social Exclusion project which conducted a major analysis of cultural taste and practices in the UK between 20032005 to assess how far Bourdieu's model in Distinction applied in contemporary Britain (see Bennett et al., 2009, as well as the wider European comparison in Prieur and Savage, 2011; 2013). The research involved focus groups, a national sample 
survey, and qualitative interviews, and constituted the most rigorous replication of Bourdieu's work since his own. One of the major findings of this project was that although the structure of cultural tastes had changed from Bourdieu's time, clear class divisions could be demonstrated, but that the key class boundaries were not the same as those identified in the Nuffield class schema (see Le Roux et al., 2008). More specifically, Le Roux et al. (2008) showed that lower managers were more like the intermediate class in their cultural orientations than they were to the "service class". This opened the way for Bourdieusian perspectives to more directly engage with Goldthorpe's models of class (see also Savage, Warde and Devine, 2005). This growing confidence of Bourdieusian perspectives to challenge conventional models is not confined to the CCSE study, however, as the work of Will Atkinson (2011; 2014; 2015) testifies (and see other examples such as Li et al., 2008, Scherger and Savage, 2010; Warde 2011, and also the discussion in Flemmen 2013).

It is in this context that the Great British Class Survey project (Savage et al., 2013 ; 2015a; 2015b) proved to be so important, as it brought to a head new ways of conceptualising class influenced by Bourdieu in contestation with more traditional perspectives, not only Goldthorpe's but also Marxist (Toscano, 2015), culturalist (Skeggs, 2015) and Weberian perspectives. The GBCs team argued that the conventional fixation on the boundary between middle and working classes, which was a legacy of the heroic generation, should be replaced by a greater focus on the elite at the top of the social structure, the precariat at the bottom, and a more complex range of classes in the middle ranges (see Savage et al., 2013; 2015).

There have been numerous theoretical and methodological criticisms of the GBCS (e.g. Bradley 2014; Dorling 2014; Mills, 2014; Rollock 2014 and see the reply in Savage et al., 2014; 2015), which do not concern us here. The key issue is the way that the topic of class had once more become an intense focus for debate. This was true also of the public engagement with the GBCS, which was huge. Nine million people did the BBC's "class calculator" to assess which class they were supposed to be in, and there was intense interest from the media (e.g. Martin, 2013).

The merits or otherwise of the GBCS need not concern us here. What is clear, is that class analysis has re-engaged both academic and public debate in a manner not seen since the heroic age. It has done this not by pursuing a within-paradigm or narrow approach to class, but using the concept to pose big intellectual and public questions. The resulting debates and controversies generate an energy which is rarely evident in the social sciences and offers a site of creativity and innovation. This is a remarkable opportunity for sociologists to demonstrate their leadership across the intellectual field. It is not an opportunity to be spurned. 


\section{References}

Atkinson, A. B. (2015), Inequality: what can be done? Oxford, Oxford University Press.

AtKinson, W. (2011), Class, individualization and late modernity: in search of the reflexive worker. Basingstoke, MacMillan. . (2015), Class. Cambridge, Polity. ; Roberts, S. \& SAVAGe, M. (eds.). (2013), Class inequality in austerity britain; power, difference and suffering. Basingstoke, Palgrave.

Bauman, Z. (1982), Memories of class. London, Routledge.

BECK, U. (1992), Risk society. London, Sage. . \& BECK-GERNSHEIM, E. (2002), Individualization: institutionalized individualism and its social and political consequences. London, Sage.

Bennett, T. et al. (2009), Culture, class distinction. London, Routledge.

BRADley, H. (2014), "Class descriptors or class relations? Thoughts towards a critique of savage et al.", Sociology, 48 (3): 429-436.

Butler, T. \& Savage, M. (eds.). (1995), Social change and the middle classes, London, UCL Press. CAlvert, P. (1982), The concept of class: an historical introduction. London, Hutchinson.

Crompton, R. (2008), Class and stratification. Cambridge, Polity.

Dennis, N.; Henriques, F. \& Slaughter, C. (1956), Coal is our life: an analysis of a Yorkshire mining community. London, Eyre and Spottiswode.

Devine, F. (2004), Class practices. Cambridge, Cambridge University Press. . et al. (2004), Rethinking class, identities, cultures and lifestyles, Basingstoke, Palgrave.

Dorling, D. (2014), “Thinking about class”. Sociology, 48 (3): 452-462.

Featherstone, M. (1987), "Lifestyle and consumer culture”. Theory, Culture and Society, 4 (1): 55-70.

Flemmen, M. (2013), "Putting Bourdieu to work for class analysis: reflections on some recent contributions". British Journal of Sociology, 2 (64): 325-343.

Giddens, A. (1991), The consequences of modernity. Cambridge, Polity.

Goldman, L. (2004), Science, reform, and politics in Victorian Britain: The Social Science Association 1857-1886. Cambridge, Cambridge University Press.

Goldthorpe, J. H. (1988), “Intellectuals and the working class in modern Britain”. In: Rose, D. (ed.). Social stratification and economic change. London, Hutchinson, 1988. . (1990), "A response”. In: Clark, J.; Modgil, C. \& Modgil, S. John H. goldthorpe, consensus and controversy. London, Routledge, pp. 399-440. . (2000a), On sociology. Oxford, Oxford University Press. . (2000b), "Rent, class conflict, and class structure: a commentary on Sorenson". American Journal of Sociology, 6 (105): 1572-1582. 
; Llewellyn, C. \& Payne G. (1980), Class structure and social mobility in modern Britain. Oxford, Clarendon.

.et al. (1968-1969), The affluent worker. Cambridge, Cambridge University Press, 3 vols. . \& MARSHALL, G. (1992), "The promising future of class analysis: a response to recent critiques”. Sociology, 26 (3): 381-400.

Grusky, D. B. \& Weeden, K. A. (2001), "Decomposition without death: a research agenda for the new class analysis”. Acta Sociologica, 3 (44): 203-18.

. (2008), "Are there social classes? An empirical test of the sociologist's favorite concept".

In: Conley, D. \& Lareau, A. (eds.). Social class: how does it work?. New York, Russell Sage Foundation.

HaLl, S. (1980), "Race, articulation, and societies structured in dominance". In: Sociological theories: race and colonialism. Paris, Unesco, pp. 305-345.

Hanquinet, L.; Savage, M. \& Callier, L. (2012), "Elaborating Bourdieu's field analysis in urban studies: cultural dynamics in Brussels", Urban Geography, 33 (4): 508-529.

Lash, S. \& Urry, J. (1987), The end of organised capitalism. London, Polity Press.

Le Roux, B. et al. (2008), “Class and cultural division in the UK”. Sociology, 42 (6): 1049-1071.

LI, Y.; SAVAGE, M. \& WARde, A. (2008), "Social mobility and social capital in contemporary Britain”. British Journal of Sociology, 3 (59): 391-411.

Lockwood, D. (1958), The black coated worker. Oxford, Clarendon.

Marshall, T. H. (1951), Citizenship and social class. Oxford, Oxford University Press.

Marshall, G.; Newby, H., Rose D. \& Vogler C. (1988), Social class in modern Britain. London, Hutchinson.

Martin, C. (2013), “The great vice class calculator”. Vice. Disponível em http://www.vice. com/en_uk/read/which-of-the-new-classes-are-you, consultado em 22/11/2015.

McGovern, P.; Hills, S. \& Mills, C. (2007), Market, class and employment. Oxford, Oxford University Press.

Mills, C. (2014), "The Great British class fiasco: a comment on Savage et al." Sociology, 48 (3): 437-444.

Piketty, T. (2014), Capital in the twenty first century. Boston, Mass, Harvard University Press. PLATT, J., (2003) The British Sociological Association: a sociological history. London, Routledge Prieur, A. \& Savage, M. (2013), "Emerging forms of cultural capital". European Societies, 15 (2): 246-267.

(2011), "Updating cultural capital theory: a discussion based on studies in Denmark and in Britain". Poetics, 39 (6): 566-580.

Pulzer, P. (1967), Political representation and elections in Britain. London, Allen \& Unwin, 1967.

Rollock, N. (2014) "Race, class and 'The harmony of dispositions'. Sociology, 48 (3): 445-451.

Savage, M. (1987), The dynamics of working class politics: the labour movement in Preston, 1880-1940. Cambridge, Cambridge University Press. 
. (2000), Class analysis and social transformation. Milton Keynes, Open University Press.

. (2010), Identities and social change in Britain since 1940: the politics of method. Oxford,

Oxford University Press.

. (2012), "Class, culture and politics". In: Amenta, E.; Nash, K. \& Scott, A. The

Wiley-Blackwell companion to political sociology. West Sussex, Wiley-Blackwell, pp. 294-304.

SAVAGE, M. \& GAYO, M. (2011), "Unravelling the omnivore: a field analysis of contemporary musical taste in the United Kingdom”. Poetics, 39 (5): 337-357.

SAVAGe, M.; BAgnall, G. \& Longhurst, B. J. (2001), "Ordinary, ambivalent and defensive: class identities in the North-West of England”. Sociology, 35 (4): 875-892.

Savage, M.; Warde, A. \& Devine, F. (2005), "Capital, assets and resources; some critical issues". British Journal of Sociology, 56 (1): 31-48.

(2005), Globalisation and Belonging. London, Sage.

SAVAGE, M. et al. (1992), Property, bureaucracy and culture: middle class formation in contemporary Britain. London, Routledge.

SAVAGE, M. et al. (2013), "A new model of social class? Findings from the BBC's great British class survey experiment". Sociology, 47 (2): 219-250.

Savage, M. et al. (2015), Social class in the 21st century. London, Penguin.

Scherger, S. \& SAVAge, M. (August 2010), "Cultural transmission, educational attainment and social mobility”. Sociological Review. 56 (4): 406-428.

SkegGs, B. (1997), Formations of class and gender. London, Sage.

. (2004), Class, culture, self. London, Routledge.

(2015), "Introduction: stratification or exploitation, domination, dispossession and devaluation”. Sociological Review, 63 (2): 205-222.

Sørensen, A. B. (May 2000), “Toward a sounder basis for class analysis”. American Journal of Sociology, 6 (105): 1523-1558.

Thompson, E. P. (1965), “The peculiarities of the English”. Socialist Register, 311-62.

Toscano, A. (2015), "Spectres of Marxism: a comment on Mike Savage's market model of class difference". Sociological Review, 63 (2): 512-523.

WARde, A. (1997), Consumption, food and taste. London, Sage. (2012), "Cultural hostility reconsidered". Cultural Sociology, 5 (3): 341-366.

Wright, E. O. (1985), Classes. London, Verso. . (2005), Approaches to class analysis. Cambridge, Cambridge University Press.

Willmott, P. \& Young, M. (1958), Family and Kinship in East London. London, Penguin.

Willis, P. (1975), Learning to Labour. Farnborough, Saxon House. 


\section{Resumo}

A queda e o crescimento da análise de classes na sociologia britânica, 1950-2016

Este artigo considera a natureza mutável da análise de classes na Grã-Bretanha, focalizando três gerações e com particular interesse nas razões para o ressurgimento da análise de classes nos últimos quinze anos. Mostro como a abordagem "heroica” de classe na Grã-Bretanha, que foi muito forte entre os anos 1950 e 1975, precisava destacar o papel da classe trabalhadora como agentes da mudança social progressiva. Embora isso tenha sido uma força poderosa durante esse período, ela confinou a análise de classe a um momento histórico que já estava quase sendo eclipsado, dada a escala de desindustrialização na Grã-Bretanha durante tal período. Entre 1975 e 2000, a análise de classe perdeu força na Grã-Bretanha, pois a classe trabalhadora industrial, branca e masculina parecia muito menos significante na formação da sociedade britânica. O período mais recente, desde 2000, viu um notável ressurgimento da “análise de classe cultural”, fortemente associada à influência de Pierre Bourdieu, e na parte final deste artigo esbocei o seu apelo e o seu potencial para fortalecer o estudo de classe de forma mais ampla.

Palavras-chave: Análise de classes; Pierre Bourdieu; Capitais.

\section{Abstract}

The fall and rise of class analysis in British sociology, 1950-2016

This paper considers the changing nature of class analysis in Britain, focusing on three generations, and with a particular interest in the reasons for the revival of class analysis in the past fifteen years. I show how the "heroic" approach to class in Britain, which was very strong between 1950 and 1975, depended on emphasising the role of the working class as agents of progressive social change. Whilst this was a powerful force during this period, it locked class analysis into a historical moment which was fast being eclipsed given the scale of de-industrialisation in Britain during this period. During 1975-2000 class analysis faded in Britain because the white, male, industrial working class seemed much less significant in shaping British society. The most recent period since 2000 has seen the remarkable revival of "cultural class analysis", strongly associated with the influence of Pierre Bourdieu, and I sketch out its appeal, and its potential to enhance the study of class more broadly in the final part of this paper.

Keywords: Class analysis, Pierre Bourdieu, Capitals.

Texto recebido em 1/2/2016 e aprovado em 1/2/2016. DoI: 10.11606/0103-2070.Ts.2016. 110570 .

Mike SAVAGE é professor de sociologia na London School of Economics. E-mail: M.A.Savage@ lse.ac.uk. 